\title{
Setting times of Recycled Gypsum Plaster with Additives
}

\author{
Natalia Reggiani Manzo (IC), Gladis Camarini (PQ)
}

\section{Abstract}

The properties of the recycled gypsum plaster were studied by adding citric acid and tannic acid. The setting time, workability, kinetics of temperature, were measured and used as parameters to analyze how well the additives worked on gypsum plaster pastes. The results show that citric acid act as a good setting retarder as shown by the kinetics of temperature curves.

Key words: recycled gypsum plaster, setting time, citric acid, tannic acid.

\section{Introduction}

The recycled gypsum is a great alternative to avoid waste and wrong destination to gypsum waste, as well exploration of gypsum deposits. However, the recycled gypsum plaster has its setting time reduced, which can prevent it to be used widely by the industry.

In order to introduce the recycled gypsum on the industry, the aim of this research is to find an additive that can improve the setting time and workability of the recycled gypsum plaster, without reducing the mechanical properties.

\section{Results and Discussion}

The citric acid and tannic acid and were studied. The setting time was measured with Vicat apparatus and by kinetics of temperature.

The recycled gypsum was produced in the laboratory, according the method described by Pinheiro ${ }^{1}$. The water/gypsum plaster ratio used was 0,7 .

Figures 1 and 2 show the results of kinetics of temperature. The citric acid is a better setting time retarder than tannic acid. For the citric acid, as the concentration is increased, the peak of temperature is delayed. The results were not the same for tannic acid.

Figure 1. Kinetics of temperature curves with citric acid.

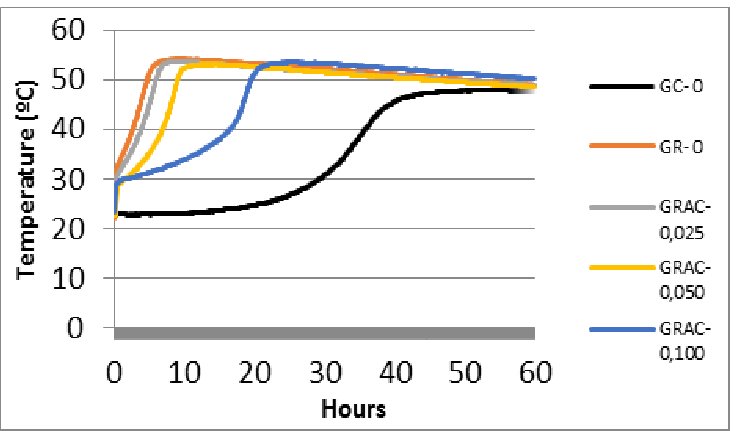

The citric acid is a good setting time retarder and it can enhance the gypsum plaster workability.
However, it reduces the mechanical properties. Some authors explain that the citrate ions reacts with the gypsum increase the setting time and the change in the microstructure decrease its strength 2,3 . Tannic acid does not reduce the mechanical properties of the recycled gypsum plaste, but the consistency and the setting time are slightly enhanced.

Figure 2. Kinetics of temperature curves with tannic acid.

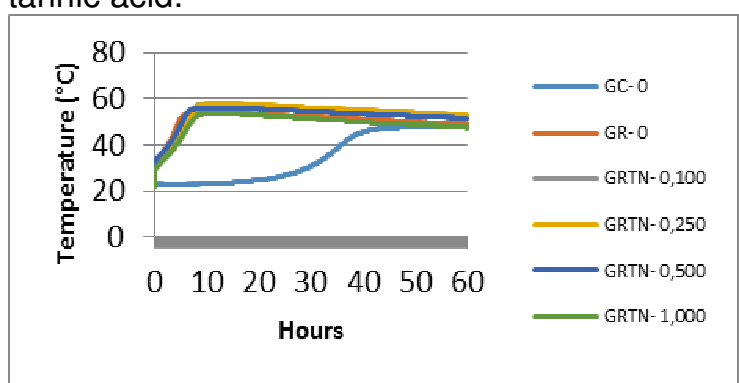

\section{Conclusions}

From this research, it can be concluded that the citric acid is a better setting time retarder than tannic acid. However, it reduces the mechanical properties, which can prevents its use on the gypsum plaster industry.

\section{Acknowledgement}

The authors are grateful to São Paulo Research Foundation (FAPESP) and the National Councel for Scientific and Technological Development (CNPq) for providing scholarships for this research (IC and PQ).

\footnotetext{
PINHEIRO, S. M. de M. Gesso Reciclado: avaliação de propriedades para uso em componentes. 303 p. Tese (Doutorado) - Faculdade de Engenharia Civil, Universidade Estadual de Campinas, Campinas, 2011.

2 HENAO, A.H.; CINCOTTO, M.A., Seleção de substâncias retardadoras do tempo de pega do gesso de construção. São Paulo: Escola Politécnica, USP, 1997. (Boletim Técnico).

BADENS et al. Crystallization of gypsum from hemihydrate in presence of additives. Journal of Crystal Growth. v. 198/199. p. 704$709,1999$.
} 